Jürgen Martschukat

\title{
Identifying, Categorizing, and Stigmatizing Fat Bodies
}

\section{The Malleable Meaning of Body Shapes}

As I was flipping through the pages of Sander Gilman's book Obesity: The Biography, my curiosity was piqued by the reproduction of a chronophotograph and its caption "Eadweard Muybridge, 'A Gargantuan Woman Walking.' Collotype (1887) .... (Wellcome Collection)."1

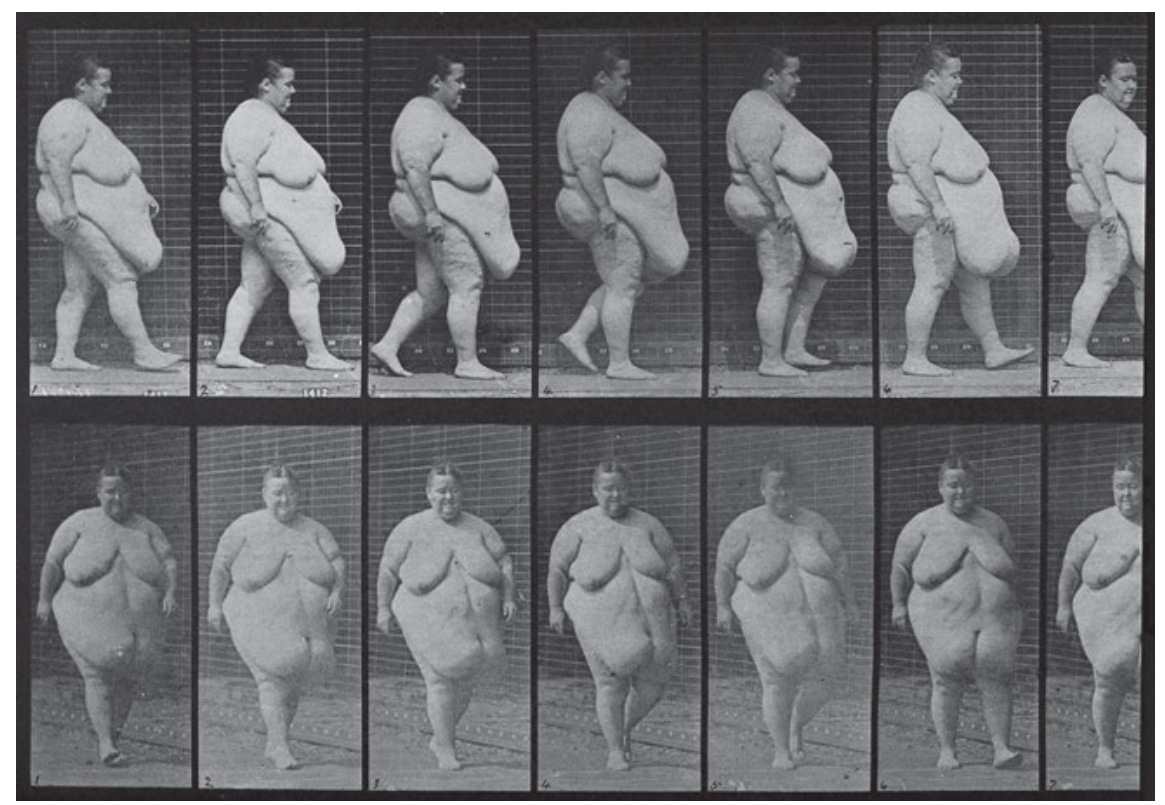

Fig. 1: Chronophotograph by Eadweard Muybridge, 1887, Wellcome Library.

1 Sander L. Gilman, Obesity: The Biography (Oxford: Oxford University Press, 2010), 108; this chapter builds on Jürgen Martschukat, "Identifying, Categorizing, and Stigmatizing Fat Bodies," Food, Fatness and Fitness: Critical Perspectives, January 1 (2018), http://foodfatnessfitness.com/2018/01/01/ identifying-categorizing-stigmatizing-fat-bodies/ (visited on March 24, 2019). 
Identifying the walking woman as "gargantuan" struck me as awkward. It led me to trace the history and meaning of this image and its caption, which - as it turns out - tells a lot about how fat bodies have been identified, categorized, and stigmatized in modern history and how this changed over time.

The woman shown in this chronophotograph performs the body technique of walking. ${ }^{2}$ Yet whereas existing research on body techniques tends to focus on the acquisition and habitualization of certain body techniques, this essay explores how walking bodies are identified, categorized, and related to certain body shapes and types and how various other cultural techniques, such as photographing, filing, and classifying, have endowed this woman's body with meaning. They tell us what she does and what she is, or rather what she is made to be in the eyes of the observer. Furthermore, this chapter argues that how images and their depictions are categorized, how they are arranged into a certain order - which then again produces a certain "truth" about human beings and their bodies - changes significantly over time. The history of this chronophotograph shows how bodies are embedded in power relations, which revolve around the administration of bodies, life and populations, and are shaped by cultural techniques. ${ }^{3}$

\section{Animal Locomotion}

From 1884 to 1887, Eadweard Muybridge shot 781 chronophotographs at the University of Pennsylvania. He titled the collection Animal Locomotion, which serves as a visual anthropology of body techniques while also very much representing the modern desire to observe, fractionalize, identify, and classify. ${ }^{4}$ We encounter a seemingly endless series of images of people throwing a punch, sitting down, turning away, and walking, walking, and walking - a focal practice of

2 The seminal article is Marcel Mauss, “The Notion of Body Techniques," Sociology and Psychology: Essays by Marcel Mauss, trans. Ben Brewster (London: Routledge and Kegan Paul, 1979), 95123. See also Erhard Schüttpelz, "Körpertechniken,” Zeitschrift für Medien- und Kulturforschung 1, 1 (2010): Kulturtechnik: 101-120.

3 Netzwerk Körper (ed.), What Can a Body Do? Praktiken und Figurationen des Körpers in den Kulturwissenschaften (Frankfurt am Main: Campus, 2012); Michel Foucault, The Birth of Biopolitics: Lectures at the Collège De France 1978-79, trans. Graham Burchell (London: Palgrave, 2008). 4 Eadweard Muybridge, Animal Locomotion: An Electro-Photographic Investigation of Consecutive Phases of Animal Movements: Prospectus and Catalogue of Plates (Philadelphia: J.B. Lippincott Company, 1887); Andreas Mayer, Wissenschaft vom Gehen: Die Erforschung der Bewegung im 19. Jahrhundert (Frankfurt am Main: Fischer, 2013), 195. 
chronophotographic research. ${ }^{5}$ Muybridge's images display many bodies almost or completely naked so as to make them better objects of observation and analysis. In June 1885, he also began to put the bodies in front of a grid pattern, which is familiar from anthropological photography.

Muybridge's work stands at a specific moment in modern history. It connects the body and society, revealing the extraordinary momentum of their ties and the body's significance in the intense longing for renewal in America in the progressive era. The late nineteenth and early twentieth centuries have been described as an age of the body in American history, when a biopolitical rationality took the enhancement of the body as its subject. ${ }^{6}$ For example, modern industrialization demanded a laboring body, whose productivity became a focal point of the contemporary sociocultural configuration. The individual body's productivity was seen as something that could be increased by making it part of a complex wheelwork of men and machines in the modern factory. Making a factory run smoothly and successfully required knowing the body's mode of operation, which was fractionalized into the smallest possible units and recomposed with other bodies and machines into a single complex operation. Muybridge's work very much interacted with the emerging contemporary concept of the "scientific management" of work processes and of society as a whole, as his chronophotography rendered bodies comprehensible, controllable, and usable. ${ }^{7}$

Furthermore, at this particular moment in history, ability and fitness were considered more crucial for the advancement of societies than ever. Next to productivity, fitness became a key term of the period, which praised competition and its powerful dynamics as key principle of societies and diagnosed the "struggle for existence" between individuals, nations, and even races as a major driving force of mankind and its history. ${ }^{8}$ This endowed the body with utmost significance for

5 Schüttpelz, "Körpertechniken," 102; Michel Frizot, "Der menschliche Gang und der kinematographische Algorythmus," in Diskurse der Fotografie: Fotokritik am Ende des fotografischen Zeitalters, ed. Herta Wolf (Frankfurt am Main: Suhrkamp, 2003), 456-478, here 456.

6 TJ Jackson Lears, Rebirth of a Nation: The Making of Modern America: 1877-1920 (New York: Harper Perennial, 2009); Jürgen Martschukat, “'The Necessity for Better Bodies to Perpetuate Our Institutions, Insure a Higher Development of the Individual, and Advance the Conditions of the Race': Physical Culture and the Shaping of the Self in Late Nineteenth and Early Twentieth Century America," Journal of Historical Sociology 24, 4 (2011): 472-493; Foucault, Birth of Biopolitics. 7 David E. Nye, America's Assembly Line (Cambridge, MA: MIT Press, 2013); the classic for the European context is Anson Rabinbach, The Human Motor: Energy, Fatigue and the Origins of Modernity (Berkeley: University of California Press, 1992).

8 Jürgen Martschukat, "The Age of Fitness: The Power of Ability in Recent American History," Rethinking History 23, 2 (2019): 157-174. A classic is Richard Hofstadter, Social Darwinism in American Thought, 1860-1915 (Boston: Beacon Press, 1992 [1944]). 
the success and even the survival of societies, groups, nations, or "races." This importance of the body made another fact thoroughly irritating: that, at the same time, many Americans fathomed themselves to be living in increasingly disembodied modern times. Members of the white urban middle-class, in particular, experienced a manic fear of developing weakened neurasthenic bodies. White men countered their fear of neurasthenia by efforts to strengthen their bodies through exercise that were at times obsessive and demanded precise observation, measurement, instruction, optimization, categorization, and differentiation of their bodies. ${ }^{9}$

Thus, it is no coincidence that Philadelphia's white middle class was most interested in Muybridge's work and supported and sponsored him financially. In the original catalogue from 1887, the first 514 plates of Animal Locomotion show men and women, mostly naked, performing some kind of movement or work effort. Male models were either sports students at the University of Pennsylvania or local craftsmen. Women were picked from all social classes; their age and size were most important to Muybridge, rather than a particular craft. In the original catalogue, Muybridge arranged the plates according to types of body techniques (such as "walking" or "arising from the ground"), and the arrangement of the images in the book was gendered in a surprisingly stereotypical manner: whereas both women and men walk, the exercising and working body is male, while the female body is graceful, caring, and often depicted with children. The erotic connotation of many images is unmissable. ${ }^{10}$

The final 219 plates of the catalogue show different animals, which are of no further interest here. However, placed between humans and animals are 27 plates in a section titled "abnormal movements." These photos include a boy without legs, a hysteric woman with spastic paralysis, and several more, with the models recruited from the poorhouse of the city of Philadelphia and set apart from the rest of the book as 'the other.' The disabled body appears as lower class and genderless, not fully human and only partly able to perform the techniques of the body. In progressive America, the disabled body encountered increasing attention from both a sensationalist public and the medical profession. ${ }^{11}$

\footnotetext{
9 Tom Lutz, American Nervousness, 1903: An Anecdotal History (Ithaca, NY: Cornell University Press, 1991); John F. Kasson, Houdini, Tarzan, and the Perfect Man: The White Male Body and the Challenge of Modernity in America (New York: Hill \& Wang, 2002).

10 Shawn Michelle Smith, At the Edge of Sight: Photography and the Unseen (Durham, NC: Duke University Press, 2013), 75-98; Elspeth H. Brown, "Racialising the Virile Body: Eadweard Muybridge's Locomotion Studies 1883-1887,” Gender \& History 17, 3 (November 2005): 627-656.

11 Kim E. Nielsen, A Disability History of the United States (Boston: Beacon Press, 2012), 88-91.
} 
Most interestingly, in this catalogue from 1887, the fat woman is hard to find. She models on two plates, which are neither part of the section on "abnormal movements" nor given any other special place in the book. She also did not play a role in the medical research on abnormal bodies that was conducted in conjunction with Muybridge's project. ${ }^{12}$ Instead, she is integrated among the first 514 plates according to the technique of the body that she is performing on the respective plate. The first plate, no. 19, is one of 58 plates depicting people walking, simply titled "walking, commencing to turn around." We do not encounter her again until plate 268, in the section on lying down and standing up. In the original, this plate is simply entitled "Arising from the ground." 13

Muybridge sold his plates in packages of one hundred to subscribers, who were interested in his work and wealthy enough to afford buying it. Yet, in the original catalogue, the fat model was not presented to customers as particularly noteworthy or as belonging to a specific category, neither by the presentation of her body nor by her placement in the collection. Very little information is provided about her. Bracketed between technical and other explanations, it indicates only that she is model no. 20, unmarried, and weighs 340 pounds. It is somewhat difficult to trace her by going through the long list of 31 pages. No special description draws the reader's attention to her body, no special categorization makes her appear different from normal, no othering of her body takes place that would define other bodies as “normal.” In Muybridge's original catalogue, she can only be identified by her number, and she simply belongs to the people walking or rising from the ground. ${ }^{14}$

When Muybridge worked on Animal Locomotion, an age of fitness and competition was just beginning to emerge in America, and body fat was only beginning to acquire the connotation of being problematic. Throughout the preceding nineteenth century, fat persons - and in particular extremely fat persons - had performed as spectacles in fairs and traveling circuses, and later in vaudeville theaters and dime museums. Fat persons served as depictions of "human

12 Marta Braun and Elizabeth Whitcombe, "Marey, Muybridge and Londe: The Photography of Pathological Locomotion," History of Photography 23 (1999): 218-224. Muybridge cooperated for this section with the neurologist Frances Derkum. See Douglas J. Lanska, "The DercumMuybridge Collaboration and the Study of Pathologic Gaits Using Sequential Photography," Journal of the History of the Neurosciences 25, 1 (2016): 23-38; Francis X. Dercum, "A Study of some Normal and Abnormal Movements Photographed by Muybridge," in Animal Locomotion: The Muybridge Work at the University of Pennsylvania: The Method and the Result, ed. University of Pennsylvania, foreword by William Pepper (Philadelphia: J.B. Lippincott, 1888), 103-133.

13 Muybridge, Animal Locomotion, Catalogue, ii, xiii.

14 Muybridge, Animal Locomotion, 13. 
ANIMAL LOCOMOTION.

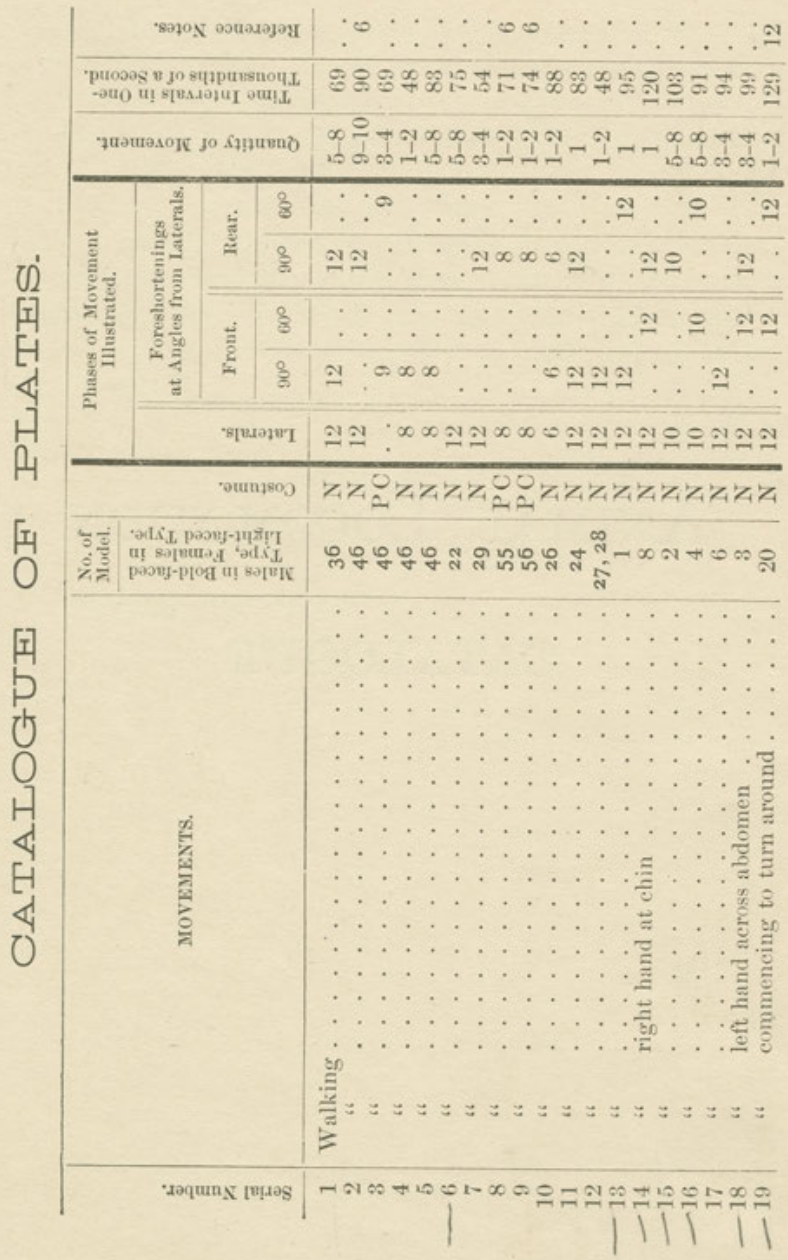

Fig. 2: Page from Muybridge, Animal Locomotion (1887), showing how difficult it is to identify our walking woman. 
grotesquery," in particular, when they were women. ${ }^{15}$ However, in general, until the late nineteenth century the meaning of body fat as sign of success was almost undisputed, and being fat rather than skinny counted as healthy. It was only in the age of fitness and of the "struggle for survival" that fat began to be perceived as an indicator of limited physical and mental ability and as a medical problem. The fat person was conceived of as lower on the evolutionary ladder and therefore also as a collective social problem. Thus, at the time when Muybridge carried out his research at the University of Pennsylvania, body fat began to change from a sign of success to an indicator of individual and collective degeneration, with the potential to marginalize those people who did not conform to the norm. In the following decades, slowly but surely and in areas ranging from everyday life to the sciences, being fat was tied to laziness, passivity, and the inability to cope with the demand for constant movement in modern life and to take good care of oneself. Body fat was also tied to femininity: even women's body cells were seen as more passive than male ones. Fat was said to resemble dead tissue, with a flabby body indicating a weak mind, as well as moral and biopolitical failure. The tone was set for the twentieth century. ${ }^{16}$

\section{3 “A Gargantuan Woman Walking”?}

After the Great Depression and World War II, the fear of fat began to gain new momentum as wealth and even abundance returned in the 1950s, at least for the growing middle class in American society. After the 1970s, this fear became stronger, and in the age of neoliberalism, when fitness and having and showing

15 Amy E. Farrell, Fat Shame: Stigma and the Fat Body in American Culture (New York: New York University Press, 2011), 32.

16 Hillel Schwartz, Never Satisfied: A Cultural History of Diets, Fantasies and Fat (London: Collier Macmillan, 1986); Peter Stearns, Fat History: Bodies and Beauties in the Modern West (New York: New York University Press, 2002), 6-9; Nina Mackert, “II want to be a fat man / and with the fat men stand': U.S.-Amerikanische Fat Men's Clubs und die Bedeutungen von Körperfett in den Dekaden um 1900,” Body Politics 3 (2014): 215-243, http://bodypolitics.de/de/wp-content/ uploads/2015/07/ Heft_3_10_mackert_fat_End.pdf (visited on March 24, 2019); Nina Mackert, "Women Are Cooler: On the Feminization of Fat," Food, Fatness and Fitness: Critical Perspectives (February 1, 2018), http://foodfatnessfitness.com/2018/02/01/women-cooler-feminization-fat/ (visited on March 24, 2019). For a most recently published historical overview see Christopher E. Forth, Fat: A Cultural History of the Stuff of Life (London: Reaktion, 2019). 
a foresighted relation to one's body became more important than ever, the fear of fat developed into an obsession. ${ }^{17}$

Fittingly, the caption that characterizes Muybridge's model no. 20 as "gargantuan" and first peaked my curiosity is a late twentieth-century invention. Yet, as I will now argue, the history of this caption is even more complex, and it reveals the twists, ramifications, and pitfalls of the meaning of fat bodies in modern history.

In 1996, this plate was given a new caption by an art historian of the Wellcome Library in London, most likely when the library introduced electronic catalogues and search systems for its impressive collection in the history of medicine and the body, which also contains hundreds of plates from Muybridge's project. ${ }^{18}$ Obviously, different from the late nineteenth-century catalogue, in the late twentieth century a fat body had to be marked by key words so that it could be easily identified and traced by researchers and search engines. Still, "gargantuan" is an awkward adjective and rarely used. It refers to big and grotesque bodies, and dictionaries provide "enormous" in connection with "appetite" to explain its meaning. Etymologically, the word can be traced back to the 1530s and François Rabelais' novels on Pantagruel - specifically to Pantagruel's father Gargantua, a giant, guzzling, farting glutton. ${ }^{19}$ Today, the use of the word to describe Muybridge's images conveys a message of physical and moral transgression. Furthermore, calling the woman "gargantuan" is - most likely unintentionally fat shaming by an art historian of the Wellcome Library, who might have a special interest in early modern French culture, or who may have just read Mikhail Bakhtin's book on Rabelais and His World..$^{20}$

Thus, it is only fairly recently that model no. 20 was described as "gargantuan," and this act of describing needs to be seen as embedded in the evolving history of body fat and its changing meanings. Nevertheless: the way the caption was put together and presented by the Wellcome collection gives the impression that the image and caption had belonged together since Eadweard Muybridge took this picture in his laboratory at the University of Pennsylvania. The caption makes it sound as if model no. 20 had always been described as "gargantuan." Its historicity is obscured, as well as the historicity of the perception of fat bodies. Furthermore, through internet platforms such as Wikimedia and Pinterest, this

17 Wendy Brown, Undoing the Demos: Neoliberalism's Stealth Resolution (New York: Zone Books, 2015); Martschukat, "The Age of Fitness"; and Das Zeitalter der Fitness: Wie der Körper zum Zeichen von Erfolg und Leistung wurde (Frankfurt am Main: Fischer, 2019).

18 Information by the Wellcome Library to the author in an email from November 4, 2017.

19 François Rabelais, Gargantua and Pantagruel (London: Penguin Classics, 2006).

20 Mikhail Bakhtin, Rabelais and His World, trans. Helene Iswolsky (Cambridge, MA: MIT Press, 1968). 
combination of image and caption has spread across the globe, finding its way into publications for academic and lay audiences. ${ }^{21}$

The story continues. In December 2009 fat activist Charlotte Cooper published a blog post on Muybridge's model no. 20. In its combination with the description as "gargantuan," Cooper writes, the images reduced the woman to her naked body; she was deprived of her humanity, just like the objects of colonial photographers. Described in an academic register (history of art and literature, anthropology), her othering is endowed with the tinge of objectivity and eternity rather than being a specifically modern phenomenon. It is an ironic twist to this story that Cooper only found the image because of its tagging. ${ }^{22}$

William Schupbach, curator of the Wellcome Collection, read and reacted to Cooper's comments in another blog post, critically reflecting upon Muybridge, fat, images, cataloguing, and its techniques. Nevertheless, in the early twenty-first century, not categorizing this woman's body seemed impossible to the Wellcome Collection. Today, fat bodies seem to demand classification, and an electronic catalogue obviously needs to serve its users' desire to search for images of fat bodies by describing and classifying its items as precisely as possible. Yet "gargantuan," Schupbach wrote, would not make any sense, and "why drag in Rabelais anyway?"23

\section{From "Gargantuan" to "Obese"}

William Schupbach replaced "gargantuan” with "obese," which meant throwing the baby out with the bathwater. As a medical term, obese expresses the normativity and politics of health, and it depicts fat bodies as in need of treatment. Furthermore, today, health and body shape are considered to be dependent on lifestyle and individual decisions, which are judged as right or wrong, good or bad. Choosing wisely, eating right, and taking good care of one's body contribute

21 See for instance https://commons.wikimedia.org/wiki/Category:Obese_women\#/media/ File:A_gargantuan_woman_walking._Collotype_after_Eadweard_Wellcome_V0048623.jpg (visited on March 24, 2019).

22 Charlotte Cooper, “Archival Images of Fat People, Pathology and Medicalisation,” Obesity Timebomb, (December 16, 2009), http://obesitytimebomb.blogspot.de/2009/12/medical-historyobesity-pathology-and.html (visited on March 24, 2019).

23 William Schupbach, “Obesity and Personality,” Wellcome Library Blog, (December 22, 2009), http://blog.wellcomelibrary.org/2009/12/obesity-and-personality/ (visited on March 24, 2019). 
substantially to being recognized as a productive member of society. ${ }^{24}$ Therefore, in the twenty-first century, "obesity" is even more moralizing and politically charged than the early modern "gargantuan." In the sixteenth century, Rabelais' text on Gargantua was humorous, ironic, and ambivalent, in contrast to the moralizing use of "obesity" today. The obesity discourse claims absolute authority when it comes to fat, with being fat presented as proof of misconduct and being unproductive, as pathological and abnormal. ${ }^{25}$

Let us take a final look at model no. 20. In a new 2010 coffee-table edition of Animal Locomotion, she is described as "a young woman, grotesquely obese, [who] is made to squat in front of Muybridge's camera to help represent the genre 'medical abnormities."' Even though "'medical abnormities"” is marked as a quote, this category does not exist in Muybridge's original. And in an article by Muybridge's co-researcher, the neurologist Francis X. Dercum, on "Normal and Abnormal Movements," model no. 20 plays no role at all; she is not even mentioned in the text. Additionally, the editors of this new luxury volume rearranged the order of things. The plates with our fat model are now placed at the very beginning of the section on "abnormal movements," in the medicalized freak show of living creatures who are depicted as unable to move properly. From 1887 to 2010, the fat woman changed from having just an ordinary body, maybe sparking some curiosity in others, into being the pathological prototype of the unhealthy body. Cultural techniques of identifying, categorizing, and tagging have substantially contributed to this transformation. ${ }^{26}$

24 Charlotte Biltekoff, Eating Right in America: The Cultural Politics of Food and Health (Durham, NC: Duke University Press, 2013); Nina Mackert and Jürgen Martschukat, "Introduction: Fat Agency,” Body Politics 7 (2015): 13-24, http://bodypolitics.de/de/wp-content/uploads/2016/01/ Heft_5_01_Mackert_Martschukat_Intro_End-1.pdf (visited on March 24, 2019).

25 Bakhtin, Rabelais and His World; Jennifer A. Lee and Cat J. Pausé, "Stigma in Practice: Barriers to Health for Fat Women,” Frontiers in Psychology 7 (2016), https://www.frontiersin.org/ articles/10.3389/fpsyg.2016.02063/full (visited on November 15, 2018). Criticizing the normativity of the health discourse does not mean one is against health; Jonathan Metzl and Anna Kirkland (eds.), Against Health: How Health Became the New Morality (New York: New York University Press, 2010).

26 Hans Christian Adam, Eadweard Muybridge: The Human and Animal Locomotion Photographs (Cologne: Taschen, 2010), 32, 564f.; Dercum, "A Study of Some Normal and Abnormal Movements." 